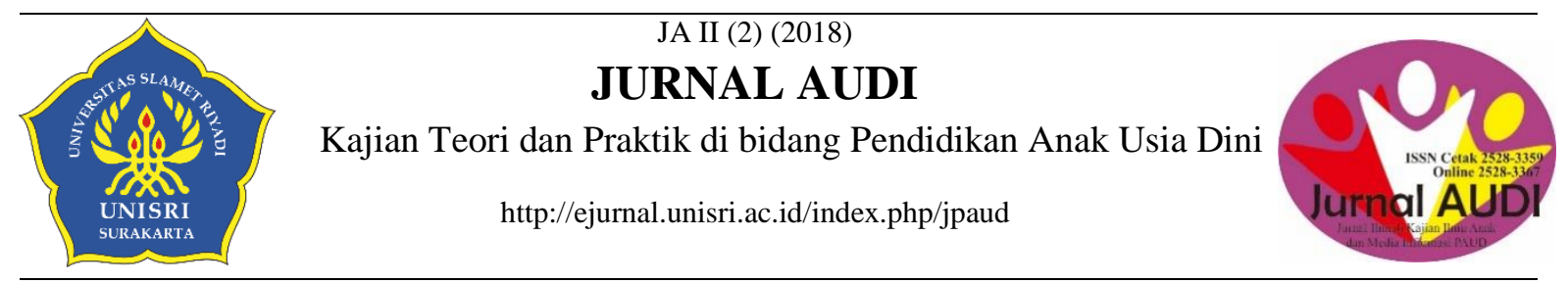

\title{
PENGGUNAAN ALAT PERMAINAN BALOK HURUF UNTUK MENINGKATKAN KEMAMPUAN MEMBACA ANAK PADA KELOMPOK B
}

Rosa Erlina Sari ${ }^{1}$, Purwadi $^{2}$

Universitas PGRI Semarang

\begin{tabular}{l}
\hline Info Artikel \\
\hline Sejarah Artikel: \\
Diterima Agustus 2017 \\
Disetujui November \\
2017 \\
Dipublikasikan Desem- \\
ber 2017 \\
\hline
\end{tabular}

Keywords:

Beams, Letters,

Reading

\begin{abstract}
Abstrak
Penelitian ini dilatar belakangi rendahnya kemampuan membaca. Hal ini disebabkan metode yang digunakan guru kurang bervariasi, kurangnya minat anak dalam membaca, siswa kecenderungan bercanda saat pelajaran sedang berlangsung, maka akan menghambat perkembangan anak dalam mempelajari kemampuan membaca siswa. Tujuan penelitian ini adalah Untuk Meningkatkan Kemampuan Membaca Anak menggunakan Alat Permainan Balok Huruf. Penelitian ini diharapkan dapat meningkatkan kemampuan membaca anak. Jenis penelitian ini adalah penelitian tindakan kelas. Subjek penelitian ini adalah lima belas anak dengan menggunakan teknik deskriptif kualitatif. Data dalam penelitian ini diperoleh melalui instrumen penelitian setelah kegiatan membaca menunjukkan adanya peningkatan dalam kegiatan membaca menggunakan balok huruf pada kelompok B di TK Pertiwi 39 Kota Semarang Tahun Pelajaran 2015/2016. Penelitian ini dilakukan dengan dua siklus diperoleh hasil peningkatan membaca anak yaitu 53,33\% pada siklus I dan $86,67 \%$ pada siklus II (indikator kinerja tercapai). Dapat disimpulkan bahwa "Penggunaan Alat Permainan Balok Huruf dapat Meningkan Kemamuan Membaca anak pada Kelompok B di TK Pertiwi 39 Kota Semarang Tahun Pelajaran 2015/2016. Saran yang dapat peneliti sampaikan, hendaknya guru memberikan pembelajaran menggunakan balok huruf untuk meningkatkan kemampuan membaca anak, sehingga target pembelajaran tercapai.
\end{abstract}

Abstract

This research is motivated poor reading skills. This is due to the method used by teachers less varied, lack of interest children in reading, students 'tendency to joke when the lesson is in progress, it will hinder the development of children in the study of students' reading ability. The purpose of this study was to Improve Children's Reading Ability to use tools Beams Letter Games. This research is expected to improve the reading skills of children. This research is a classroom action research. The subjects were fifteen children by using qualitative descriptive technique. The data in this study was obtained through the research instruments after reading indicates an increase in activity using a beam letter read in group B in the city of Semarang TK Pertiwi 39 academic year 2015/2016. This research was conducted in two cycles result is an increase in child reading $53.33 \%$ in the first cycle and $86.67 \%$ in the second cycle (indicators of performance achieved). It can be concluded that the "use of equipment Beams Games Kemamuan Reading the letters can Meningkan children in Group B in the city of Semarang TK Pertiwi 39 academic year 2015/2016. Suggestions to say, should the teacher give a lesson using a beam letters to improve the reading skills of children, so that the learning targets achieved.

Keywords: Beams, Letters, Reading

(C) 2018 FKIP Universitas Slamet Riyadi

\begin{tabular}{cr}
\hline${ }^{凶}$ Alamat korespondensi: JL. Sidodadi No. 24 & ISSN 2528-3359 (Print) \\
Semarang & ISSN2528-3367 (Online) \\
E-mail: Rosaerlina12@yahoo.com &
\end{tabular}


Rosa Erlina Sari. Penggunaan Alat Permainan Balok Huruf Untuk Meningkatkan

Kemampuan Membaca Anak Pada Kelompok B TK Pertiwi 39 Kota Semarang

\section{PENDAHULUAN}

Pendidikan Taman Kanak-Kanak merupakan salah satu bentuk pendidikan pra sekolah yang terdapat di jalur pendidikan sekolah (PP No. 27 Tahun 1990). Sebagai lembaga pendidikan pra-sekolah, tugas utama Taman Kanak-Kanak adalah mempersiapkan anak dengan memperkenalkan berbagai pengetahuan, sikap perilaku, keterampilan dan intelektual agar dapat melakukan adaptasi dengan kegiatan belajar yang sesungguhnya di Sekolah Dasar. Masa usia Taman kanak-kanak adalah masa emas (golden age) dimana pada masa itu anak mengalami perkembangan yang sangat pesat.

Masa-masa emas inilah merupakan masa pendidikan bagi anak. Dengan demikian Taman Kanak-Kanak tidak mengemban tanggung jawab utama dalam membina kemampuan akademik anak seperti kemampuan membaca dan menulis. Baca tulis dimulai dengan dengan perkembangan bahasa (Dickinson dan Tabor, 2001). Substansi pembinaan kemampuan akademik atau skolastik ini harus menjadi tanggungjawab utama lembaga pendidikan Sekolah Dasar.

Pendidikan TK yang baik tentunya dalam menjalani program-program kegiaatan pembelajaran haruslah memperhatikan faktor bawaan dan faktor lingkungan fisik, sehingga pengembangan potensi anak dapat menstimulasi secara maksimal. Di TK yang berpusat pada anak, pendidikan diharapkan melaksanakan program kegiatan pembelajaran yang menunjang aspek-aspek perkembangan anak. Oleh karena itu lingkungan (termasuk didalamnya orangtua dan guru) sangat memegang peranan penting dalam hal ini. Lingkungan harus dapat menciptakan kegiatan-kegiatan yang dapat memekarkan potensi yang ada pada anak (Depdiknas, 2004).

Realita di lapangan khususnya di TK Pertiwi 39 Semarang menunjukkan bahwa terdapat kecenderungan beberapa siswa yang kurang dalam kemampuan membaca. Hal ini disebabkan karena kurang bervariasinya penggunaan metode mengajar, yaitu guru menggunakan metode lembar kerja. Data ini diperoleh dari pengamatan langsung di lapangan serta wawancara yang dilakukan kepada guru kelas. Gejala diatas ditandai dengan adanya ciri-ciri sebagai berikut : siswa malas dalam menerima pelajaran di kelas, tidak mau mengerjakan tugas pembelajaran yang diberikan oleh guru, kurangnya minat anak dalam membaca, dan siswa kecenderungan bercanda dengan teman saat pembelajaran berlangsung.

Berbagai upaya telah dilakukan oleh guru-guru di TK Pertiwi 39 Semarang. Beberapa metode yang biasa digunakan seperti bercerita, pemberian tugas, praktek langsung, tanya jawab, karyawisata, demonstrasi dan bermain peran. Namun, upaya-upaya yang dilakukan guru belum mampu mencapai hasil yang optimal. Salah satu alternatif yang penulis lakukan yaitu menerpkan metode permainan balok huruf. Dengan balok huruf siswa dapat belajar dalam mengenal huruf dan menghubungkan huruf menjadi kata.

Dengan melalui balok huruf diharapkan anak akan lebih tertarik dan meningkatkan minat anak untuk berpartisipasi dalam proses pembelajarannya. Dalam rangka mengembangkan persoalan tersebut, penulis mencoba untuk melakukan penelitian tentang bagaimana meningkatkan kemampuan membaca anak melalui penggunaan alat permainan balok huruf.

Berdasarkan latar belakang masalah diatas, maka beberapa faktor yang menjadi masalah dalam penelitian di identifikasikan sebagai berikut:

1. Rendahnya kemampuan membaca siswa di kelompok B TK Pertiwi 39 Semarang.

2. Metode membaca yang digunakan di kelompok B TK Pertiwi 39 Semarang kurang bervariasi.

3. Sebagian besar peserta didik di TK Pertiwi 39 Kota Semarang kurang minat dalam pembelajaran membaca.

4. Penerapan membaca dengan media balok huruf masih jarang diterapkan dalam proses belajar mengajar khususnya di TK Pertiwi 39 Kota Semarang.

5. Penerapan media balok huruf dalam membaca dapat meningkatkan 
Rosa Erlina Sari. Penggunaan Alat Permainan Balok Huruf Untuk Meningkatkan

Kemampuan Membaca Anak Pada Kelompok B TK Pertiwi 39 Kota Semarang

perkembangan membaca pada TK

Pertiwi 39 Kota Semarang.

6. Kurang diterapkannya metode pembelajaran yang cocok dan menarik di TK Pertiwi 39 Kota Semarang.

\section{Pembatasan Masalah}

Berdasarkan identifikasi masalah diatas maka penelitian ini hanya membatasi pada penggunaan alat permainan balok huruf untuk meningkatkan kemampuan membaca anak dengan tema aku di kelompok B TK Pertiwi 39 Kota Semarang Tahun Pelajaran 2015/2016.

\section{Perumusan Masalah}

Berdasarkan latar belakang yang telah dipaparkan diatas maka rumusan masalah penelitian ini adalah bagaimana penggunaan alat permainann balok huruf dapat meningkatkan kemampuan membaca anak di TK Pertiwi 39 Kota Semarang?

\section{Tujuan Penelitian}

Penelitian ini secara umum bertujuan untuk meningkatkan kemampuan membaca siswa menggunakan alat permainan balok huruf pada peserta didik di TK Pertiwi 39 Kota Semarang.

\section{Kajian Teori}

Menurut Hodgson dalam Tarigan (2008: 7) membaca adalah suatu proses yang dilakukan serta dipergunakan oleh pembaca untuk memperoleh pesan, yang hendak disampaikan oleh penulis melalui media kata-kata / bahasa tulis. Suatu proses yang menuntut agar kelompok kata yang merupakan suatu kesatuan akan terlihat dalam suatu pandangan sekilas dan makna kata-kata secara individual akan dapat diketahui.

Menurut Anderson dalam Dhieni (2005: 5.5) memandang membaca sebagai suatu proses untuk memahami makna suatu tulisan. Sedangkan menurut Klein, dkk dalam Rahim (2007: 3) mengemukakan bahwa definisi membaca mencangkup (1) membaca merupakan suatu proses, (2) membaca adalah strategis, dan (3) membaca merupakan interaktif.

Menurut Damaianti dalam Harras, dkk., (2003: 3) mengemukakan bahwa membaca merupakan hasil interaksi antara persepsi terhadap lambang-lambang yang mewujudkan bahasa melalui keterampilan berbahasa yang dimiliki pembaca dan pengetahuannya tentang alam sekitar.

Tahapan membaca menurut Finocchiaro dan Bonomo dalam Tarigan (2008: 18-20) adalah:

1. Membaca bahan yang telah dipelaji dan mengucapkannya dengan baik atau bahan bahan yang mungkin telah diingat.

2. Menyusun kata-kata serta strukturstruktur yang telah diketahui menjadi bahan dialog atau paragraf yang beraneka ragam.

3. Membaca gambar yang berisi sejumlah kata dan struktur yang masih asing atau belum biasa.

4. Beberapa spesialis dalam bidang membaca menganjurkan penggunaan teks-teks sastra yang telah disederhanakan atau majalah-majalah sebagai bahan bacaan.

5. Pada tahap ini bahan bacaan tidak dibatasi.

Menurut seorang pakar Cochrane dalam Aulia (2011: 28-29) perkembangan dasar kemampuan membaca pada anak usia 4-6 tahun berlangsung dalam lima tahap yakni: (1)Fantasi, (2)Pembentukan konsep diri, (3)Membaca gambar, (4)Pengenalan bacaan, (5)Membaca lancar.

Menurut Blanton, dkk dalam Rahim (2007: 11-12) tujuan membaca mencangkup (1) kesenangan, (2) menyempurnakan membaca nyaring, (3) menggunakan strategi tertentu, (4) memperbaharui pengetahuannya tentang suatu topik, (5) mengaitkan informasi baru dengan informasi yang telah diketahuinya, (6) memperoleh informasi untuk laporan lisan atau tertulis, (7) mengkonfirmasikan atau menolak prediksi, (8) menampilkan suatu eksperimen, (9) menjawab pertanyaan-pertanyaan yang spesifik.

Leonhardt dalam dhieni, dkk (2005: 5.4) berpendapat bahwa membaca sangat penting bagi anak. Anak-anak yang gemar membaca akan mempunyai rasa kebahasaan yang lebih tinggi. Anak akan berbicara, menulis dan memahami gagasan-gagasan rumit secara lebih baik. Kegemaran membaca harus dikembangkan sejak dini. Sejalan 
Rosa Erlina Sari. Penggunaan Alat Permainan Balok Huruf Untuk Meningkatkan

Kemampuan Membaca Anak Pada Kelompok B TK Pertiwi 39 Kota Semarang dengan pendapat ini Montessori dan Hainstock mengemukakan bahwa pada usia 4-5 tahun anak sudah bisa diajarkan membaca dan menulis. Bahkan membaca dan menulis merupakan permainan yang menyenangkan bagi anak usia ini.

Browman dalam Wasik (2008: 355) berpendapat bahwa anak-anak belajar mengenali huruf-huruf dan kata-kata dan akhirnya menjadi sadar akan hubungan antara bunyi dan huruf dan kata-kata.Anak-anak yang berusia dini dapat mempelajari sesuatu dengan mudah dan cepat.

Balok huruf merupakan salah satu ragam dari alat permainan edukatif. Menurut Soetjiningih dalam Rolina (2012: 6) mengatakan bahwa alat permainan edukatif adalah alat yang dapat mengoptimalkan perkembangan anak, disesuaikan dengan usianya, tingkat perkembanganya, serta berguna untuk perkembangan fisik-motorik (motorik kasar dan motorik halus), bahasa, kognitif, dan sosial.

Sedangkan menurut Ruiz dkk. dalam Asyar (2012: 11) mengatakan alat peraga digunakan oleh guru untuk member penekanan pada informasi, memberikan stimulasi perhatian, dan memfasilitasi proses pembelajaran. Sementara Sanaky dalam Asyar (2012: 12) mengartikan alat peraga sebagai suatu alat bantu yang dipergunakan oleh pebelajar untuk memperagakan materi pelajaran.

Menurut Sudono (2000: 7) alat permainan adalah semua alat bermain yang digunakan oleh anak untuk memenuhi naluri bermainnya dan memiliki berbagai macam sifat seperti bongkar pasang, mengelompokkan, memadukan, mencari padanannya, merangkai, membentuk, mengetok, menyempurnakan suatu desain, atau menyusun sesuai bentuk utuhnya.

Menurut Zaman dalam Rolina (2012: 8) fungsi APE adalah sebagai berikut: (1) menciptakan suasana bermain yang menyenangkan bagi anak dalam proses pemberian perangsangan indicator kemampuan anak; (2) Menumbuhkan rasa percaya diri dan membentuk citra diri anak yang positif; (3) memberikan stimulus dalam pembentukan perilaku dan pengembangan kemam-

puan dasar merupakan fokus pengembangan anak usia dini; (4) memberikan kesempatan anak bersosialisasi,berkomunikasi dengan teman sebaya.

Pendapat yang hampir sama dikemukakan oleh Soetjiningsih dalam Rolina (2012: 11) yang menyatakan APE adalah: (1) mengembankan aspek fisik, yaitu kegiatan-kegiatan yang menunjang atau merangsang pertumbuhan fisik anak; (2) mengembankan aspek bahasa, dengan melatih berbicara, menggunakan kalimat yang benar; (3) mengembankan aspek kognitif, yaitu dengan pengenalan suara, ukuran, bentuk, warna, dll; (4) mengembankan aspek sosial, khususnya dalam hubungannya dengan interaksi antara ibu dan anak, keluarga dan masyarakat.

Menurut Sudono (2000: 8) alat permaian berfungsi untuk mengenal lingkungan dan membimbing anak untuk mengenali kekuatan maupun kelemahan dirinya. Anak didik secara aktif melakukan kegiatan permainan dan secara optimal menggunakan seluruh pancainderanya secara aktif. Kegiatan atau permainanyang menyenangkan juga akan meningkatkan aktifitas sel otak mereka.

Balok huruf yang terdiri dari enam sisi yang berisi dengan huruf-huruf yang berbeda pada setiap sisinya dirancang sebagai media pembelajaran dalam rangka meningkatkan perkembangan membaca. Permainan balok huruf dapat melatih kemampuan anak dalam mengenal lambang huruf, kata, dan warna.

Cara bermainnya sangat sederhana, cukup melambungkan balok huruf kemudian menyebutkan huruf apa yang muncul. Namun sebelum memulai permainan hendaknya guru mengenalkan terlebih dahulu tentang balok huruf tersebut. Seperti balok memiliki enam buah sisi, perlihatkan setiap sisi dari balok tersebut. Kemudian terangkan disetiap sisi berisi huruf yang berbeda.

Meningkatkan kemampuan membaca anak dengan menggunakan metode bermain balok huruf akan mampu merangsang anak agar menumbuhkan kemampuan berfikirnya, kemampuan mengingatnya, lebih memusatkan perhatiannya, mampu 
Rosa Erlina Sari. Penggunaan Alat Permainan Balok Huruf Untuk Meningkatkan

Kemampuan Membaca Anak Pada Kelompok B TK Pertiwi 39 Kota Semarang mengembangkan keterampilan sosial anak dan mengurangi kecemasan pada anak karena bermain merupakan hal yang menyenangkan bagi anak.

Anak usia dini adalah sosok individu yang sedang menjalani suatu proses perkembangan dengan pesat dan fundamental bagi perkembangan yang selanjutnya. Menurut Berk dalam Nurani (2009: 6) pada masa ini proses pertumbuhan dan perkembangan dalam berbagai aspek sedang mengalami masa yang cepat dalam rentang perkembangan hidup manusia.

Sesuai dengan pasal 28 Undangundang Sistem Pendidikan Nasional No. 20/ 2003 ayat 1 , yang termasuk anak usia dini adalah anak yang masuk dalam rentang usia 0-6 tahun. Menuruta Mansur (2005: 88) anak usia dini adalah kelompok anak yang berada dalam proses pertumbuhan dan perkembangan yang khusus sesuai dengan tingkat pertumbuhan dan perkembangannya.

Ramli (2005: 185) menyatakan masa usia Taman Kanak-Kanak (TK) merupakan masa-masa dalam kehidupan manusia yang berentang sejak usia empat tahun sampai enam tahun. Masa ini berada pada bagian tengah dan masa akhir dalam kehidupan manusia. Sedangkan Masitoh (2006: 1.16) menyatakan anak usia dini adalah sekelompok anak yang berada dalam proses pertumbuhan dan perkembangan yang bersifat unik, artinya karakteristik pertumbuhan dan perkembangan fisik, motorik, kognitif, atau intelektual (daya pikir, daya cipta), sosialemosional, serta bahasa.

Lebih lanjut, Morrison (2012: 253) menyatakan anak TK sama seperti anak-anak lain dalam banyak hal. Mereka memiliki karakteristik perkembangan, fisik, dan perilaku yang menandakan mereka adalah anak TK (anak-anak usia 5-6 tahun). Namun pada saat yang sama, mereka memiliki karakteristik yang menjadikan mereka individuindividu yang unik.

Berdasarkan berbagai sumber di atas dapat disimpulkan bahwa anak usia 0-6 tahun yaitu sosok individu yang memiliki karakteristik khusus baik dari segi kognitif, sosial, emosi, bahasa, fisik maupun motorik, yang sedang mengalami pertumbuhan dan

perkembangan yang sangat pesat, sehingga diperlukan stimulasi yang tepat agar dapat tumbuh dan berkembang dengan maksimal.

\section{METODE PENELITIAN Objek Penelitian}

Penelitian ini dilakukan pada siswa TK Pertiwi 39 Semarang sejumlah 5 anak laki-laki dan 10 anak perempuan. Dari jumlah siswa tersebut memiliki tingkat kecerdasan intelejensi yang beragam yaitu 5 siswa pandai 7 siswa sedang dan lainya yaitu 3 siswa kurang dan tidak pandai.

\section{Teknik Pengumpulan Data} Data

Data penelitian yang dikumpulkan berupa informasi tentang kemampuan siswa dalam aspek kemampuan membaca yang terdiri dari (1)anak menghubungkan dan menyebutkan tulisan sederhana dengan simbol yang melambangkanya; (2)anak meniru kembali 4-5 urutan kata; (3)menghubungkan gambar dengan kata; (4)anak membaca gambar yang memiliki kata/kalimat sederhana. Data penelitian dikumpulkan dari berbagai sumber yang meliputi:

\section{Wawancara}

Wawancara, yaitu mencari informasi dengan cara bertanya langsung kepada Informan atau narasumber, yaitu anak didik TK Pertiwi 39 Semarang.

\section{Observasi}

Observasi, yaitu mengamati tempat dan peristiwa atau kejadian berlangsungnya pembelajaran membaca dengan alat permainan balok huruf di TK Pertiwi 39 Semarang.

\section{Dokumentasi}

Dokumentasi, yaitu mencari informasi dengan objek Dokumen atau arsip, antara lain berupa satuan bidang pengembangan, pedoman observasi, dan hasil penilaian anak.

\section{Analisis}

Analisis data dalam penelitian tindakan kelas ini menggunakan analisis kuantitatif dan kualitatif. Terhadap peningkatan kemampuan membaca dianalisis secara kuantitatif dengan memberikan skor (1, 2, dan 3).

\section{PEMBAHASAN \\ Analisis Data \\ Tabel 1. Kemampuan Membaca Siklus I}


Rosa Erlina Sari. Penggunaan Alat Permainan Balok Huruf Untuk Meningkatkan

Kemampuan Membaca Anak Pada Kelompok B TK Pertiwi 39 Kota Semarang

\begin{tabular}{|l|l|c|c|}
\hline Indikator & \multirow{2}{*}{$\begin{array}{c}\text { Nilai } \\
\text { Membaca }\end{array}$} & \multicolumn{2}{|c|}{3} \\
\cline { 3 - 4 } & Jumlah anak & Presentase \\
\hline \multirow{2}{*}{$\begin{array}{l}\text { Membaca } \\
\text { dengan } \\
\text { balok hu- } \\
\text { ruf }\end{array}$} & Baik (3) & 8 & $53,7 \%$ \\
\cline { 3 - 4 } & Cukup (2) & 5 & $33,3 \%$ \\
\hline \multicolumn{2}{|l}{ Jumlah } & 2 & $13,3 \%$ \\
\hline
\end{tabular}

Berdasarkan tabel diatas, hasil lembar observasi tersaji dalam diagram dibawah ini:

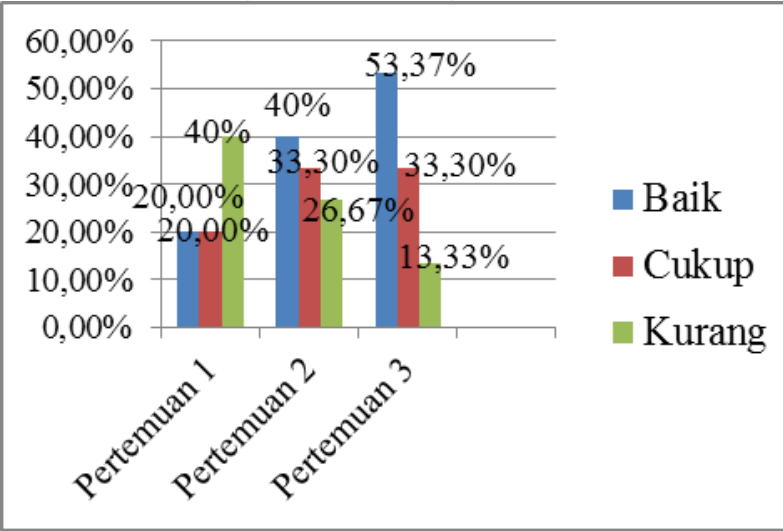

Gambar 1. Hasil observasi pada siklus I

\section{Pembahasan Hasil Analisis Data}

Berdasarkan hasil observasi

kemampuan membaca anak melalui permainan balok huruf, dapat diketahui ternyata baru $53,37 \%$ anak yang menunjukkan tingkat kemampuan dalam membaca.

Tabel 2. Kemampuan membaca anak siklus

\begin{tabular}{|l|c|c|c|}
\multicolumn{1}{c|}{ II } \\
\hline \multirow{2}{*}{ Indikator } & & \multicolumn{2}{|c|}{3} \\
\cline { 2 - 4 } & Presentase & \multicolumn{2}{|c|}{ Jumlah anak } \\
\hline \multirow{3}{*}{$\begin{array}{l}\text { Membaca } \\
\text { dengan } \\
\text { balok huruf }\end{array}$} & $53,3 \%$ & 13 & $86,7 \%$ \\
\cline { 2 - 4 } & $40 \%$ & 2 & $13,3 \%$ \\
\cline { 2 - 4 } & $6,67 \%$ & 0 & $0 \%$ \\
\hline Jumlah & 15 & $100 \%$ \\
\hline
\end{tabular}

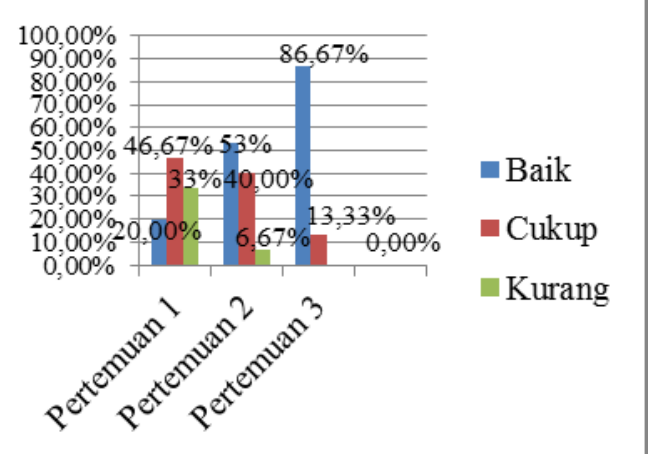

Gambar 2. Hasil observasi pada siklus II

Berdasarkan hasil observasi kemampuan membaca anak melalui permainan balok huruf dapat diketahui bahwa peningkatan membaca anak menjadi $86,67 \%$ anak yang menunjukkan kemampuan membaca anak dalam melakukan permainan.

Berdasarkan hasil penelitian pada siklus I dan II menunjukkan bahwa menggunakan permainan balok huruf dalam kegiatan bermain, dapat meningkatkan kemampuan membaca anak pada kelompok B TK Pertiwi 39 Tahun Ajaran 2015/2016. Hal ini terlihat dari pengamatan yang dilakukan oleh peneliti terhadap kemampuan dalam proses pembelajaran membaca anak pada peningkatan kemampuan membaca anak siklus I yang megalami peningkatan pada siklus II.

Secara umum presentase siswa pada siklus I masih belum memenuhi indikator kinerja. Berdasarkan pada kekurangan siklus I anak masih belum fokus pada penjelasan yang diterangkan oleh guru. Maka dari itu, guru berusaha membuat perencanaan yang lebih menarik pada kegiatan pembelajaran predentałsus II. Hal ini dilakukan agar anak dapat menerima pembelajaran dengan maksimal.

Pada siklus II tahap pelaksanaannya guru lebih mengkondisikan anak secara menyeluruh sebelum pelajaran dimulai. Kemudian bernyanyi bersama dan guru menunjukkan bagaimana cara bermain balok huruf dan hasil permainan merangkai kata dengan balok huruf sudah menujukkan hasil yang maksimal. 
Rosa Erlina Sari. Penggunaan Alat Permainan Balok Huruf Untuk Meningkatkan

Kemampuan Membaca Anak Pada Kelompok B TK Pertiwi 39 Kota Semarang

Tabel 3. Peningkatan hasil belajar anak dalam kemampuan membaca antara siklus I dan siklus II

\begin{tabular}{|c|c|c|c|c|}
\hline Aspek & $\begin{array}{c}\text { Ketera } \\
\text { ngan }\end{array}$ & $\begin{array}{c}\text { Kondisi } \\
\text { Awal }\end{array}$ & Siklus I & $\begin{array}{c}\text { Siklus } \\
\text { II }\end{array}$ \\
\hline $\begin{array}{c}\text { Kemam } \\
\text { puan } \\
\text { memba } \\
\text { ca anak }\end{array}$ & Baik & $26,67 \%$ & $53,34 \%$ & $86,67 \%$ \\
\cline { 2 - 5 } & Cukup & $26,67 \%$ & $33,33 \%$ & $13,33 \%$ \\
\cline { 2 - 5 } & $\begin{array}{c}\text { Kuran } \\
\text { g }\end{array}$ & $46,66 \%$ & $13,33 \%$ & $0 \%$ \\
\hline
\end{tabular}

Dari tabel dapat dilihat bahwa nilai yang tuntas pada siklus I belum memuaskan, meskipun telah mengalami kenaikan pada siklus II. Pada siklus I mengalami ketuntasan sebesar 53,34\% dan ketidaktuntasan sebesar $33,33 \%$. Sedangkan pada siklus II mengalami ketuntasan $86,67 \%$ dan tidak mengalami ketuntasan sebesar $13,33 \%$.

Berdasarkan tabel diatas, perkembangan membaca anak pada siklus I dan siklus II dapat digambarkan dengan diagram dibawah ini:

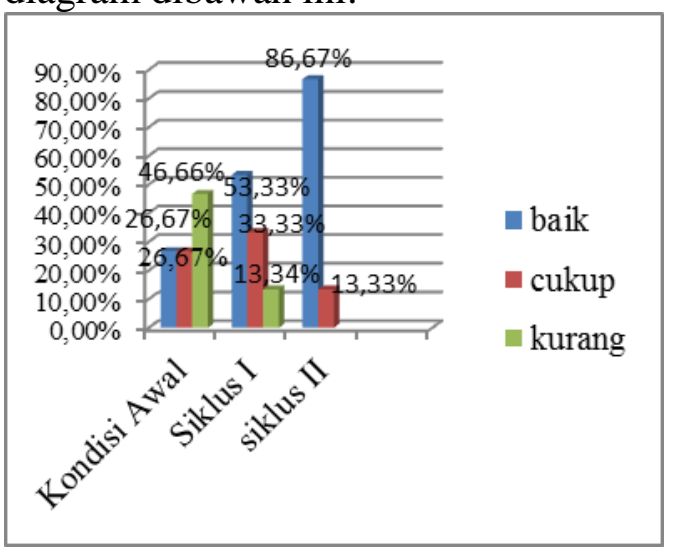

Gambar 3. Perkembangan Membaca

Hasil yang dicapai ini tentu saja sangat dipengaruhi kondisi siswa, seperti siswa masih kurang terbiasa melakukan kegiatan secara langsung pada proses pembelajaran dan kurang fokus saat guru sedang menjelaskan. Itulah kelemahan siswa dalam siklus I.

Peningkatan hasil belajar dalam siklus II karena adanya penyempurnaan dari beberapa kekurangan pada siklus I sehingga ketuntasan sebesar $86,67 \%$ dan ketidak tuntasannya $13,33 \%$. Dari penjelasan tersebut ada peningkatan kemampuan membaca anak melalui permainan balok huruf pada kelompok B TK Pertiwi 39 Kecamatan Mijen Kota Semarang.

\section{PENUTUP}

Berdasarkan ,hasil kegiatan penelitian tindakan kelas dalam keseluruhan pembahasan dan analisis yang telah dilakukan, dapat dibuktikan bahwa menggunakan permainan balok huruf dapat meningkatkan kemampuan membaca anak pada kelompok B TK Pertiwi 39 Kecamatan Mijen Kota Semarang Tahun Ajaran 2015/2016.

Hal ini dapat terlihat dari hasil dalam peningkatan perkembangan kegiatan penelitian, yaitu pada tahap observasi awal $26,67 \%$ yang meningkat pada siklus I yaitu $53,33 \%$ dan meningkat kembali pada siklus II sebesar 86,67\% dengan hasil tersebut maka siklus III tidak diperlukan. Hal tersebut didukung oleh teori Soetjiningsih dalam Rolina (2012:11) yang menyatakan tujuan alat peraga edukatif adalah : (1) mengembankan aspek fisik, yaitu kegiatankegiatan yang menunjang atau merangsang pertumbuhan fisik anak; (2) mengembankan aspek bahasa, dengan melatih berbicara, menggunakan kalimat yang benar; (3) mengembankan aspek kognitif, yaitu dengan pengenalan suara, ukuran, bentuk, warna, dll; (4) mengembankan aspek sosial, khususnya dalam hubungan dengan interaksi ibu dan anak, keluarga dan masyarakat.

\section{Kesimpulan}

Berdasarkan analisis tersebut maka dapat ditarik kesimpulan dari hasil penelitian yang sejalan dengan hipotesis penelitian yang berbunyi bahwa "Meningkatkan kemampuan membaca anak melalui permainan balok huruf pada kelompok B TK Pertiwi 39 Kecamatan Mijen Kota Semarang" dapat diterima keberadaannya.

\section{Saran}

Berdasarkan kesimpulan diatas, maka saran yang dapat peeliti sampaikan adalah sebagai berikut:

1. Sebaiknya permainan balok huruf dapat diterapkan dalam pembelajaran karena permainan balok huruf adalah salah satu alternatif media pembelajaran yang mengajak anak untuk belajar membaca selain itu balok huruf juga 
Rosa Erlina Sari. Penggunaan Alat Permainan Balok Huruf Untuk Meningkatkan Kemampuan Membaca Anak Pada Kelompok B TK Pertiwi 39 Kota Semarang bermanfaat utuk anak yaitu anak dapat mengenal warna.

2. Sebaiknya guru lebih kreatif dan inovatif menciptakan permainan dalam pembelajaran di TK agar pembelajaran lebih menarik dan dapat meningkatkan kemampuan membaca anak sehingga anak menjadi lebih mengenal bacaan yang ada di lingkungan sekitar.

\section{DAFTAR PUSTAKA}

Aulia. 2011. Mengajarkan Balita Anda Membaca. Yogyakarta: Intan Media.

Dhieni, Nurbiana, dkk. 2006. Metode Pengembangan Bahasa. Jakarta: Universitas Terbuka.

Hasan, Maimunah. 2009. PAUD (Pendidikan Anak Usia Dini). Yogyakarta: Diva Press.

http://ejournal.fip.unp.ac.id/index.php/paud/a rticle/view/1704/1473

http://ejournal.undiksha.ac.id/index.php/JJPA UD/article/view/3342

Musfiroh, Tadkiroatun. 2009. Menumbuh Kembangkan Baca Tulis Anak Usia Dini. Jakarta: Grasindo.

Rahim, Farida. 2005. Pengajaran Membaca di Sekolah Dasar. Jakarta: Bumi Aksara. 